\title{
EFEK LARVISIDA RESIDU MINYAK ATSIRI BUNGACENGKEH (Syzygium aromaticum L.) TERHADAP LARVA INSTAR III NYAMUK Aedes aegypti DI LABORATORIUM
}

\author{
Devita $\mathrm{N}^{1}$, Isti'anah $\mathrm{S}^{2}$ \\ ${ }^{1}$ Mahasiswa Fakultas Kedokteran Universitas Islam Indonesia \\ ${ }^{2}$ Departemen Parasitologi Fakultas Kedokteran Universitas Islam Indonesia
}

\begin{abstract}
ABSTRAK
Latar Belakang

Pemberantasan vektor secara alami adalah salah satu cara pengendalian demam berdarah dengue. Minyak atsiri bunga cengkeh diketahui memiliki efek larvisida.Syarat larvisida yang baik adalah memiliki persistensi yang cukup lama.
\end{abstract}

\section{Tujuan}

Mengetahui efek larvisida residu minyak atsiri bunga cengkeh (Syzygium aromaticum L.) terhadap larva instar III nyamuk Ae. Aegypti.

\section{Metode}

Penelitian ini bersifat eksperimental laboratorium dengan rancangan randomized post test only control group design. Larva dibagi menjadi 4 kelompok dimana tiap kelompok terdiri dari 25 ekor larva dengan konsentrasi $0,03 \% \mathrm{v} / \mathrm{v}, 0,3 \% \mathrm{v} / \mathrm{v}, 3 \% \mathrm{v} / \mathrm{v}$, dan kontrol. Pengukuran mortalitas dilakukan setelah 48 jam perlakuan,setelah satu minggu, larva baru dimasukkan kemudian diamati mortalitasnya. Hal ini dilakukan pada minggu ke I,II,III dan IV.

\section{Hasil}

Residu minyak atsiri bunga cengkeh dengan konsentrasi 0,03\% v/v memiliki efek larvisida sebesar $91,33 \%$ pada minggu I, sebesar $82,67 \%$ pada minggu II, sebesar $37,33 \%$ pada minggu III, dan sebesar $14 \%$ pada minggu ke IV. Sedangkan pada residu minyak atsiri bunga cengkeh konsentrasi $0,3 \% \mathrm{v} / \mathrm{v}$ dan $3 \% \mathrm{v} / \mathrm{v}$ memiliki efek larvisida terhadap larva instar III nyamuk Ae.aegyptisebesar 100\% pada minggu I, II, III, dan IV.

\section{Kesimpulan}

Residu minyak atsiri bunga cengkeh memiliki efek larvasida.

Kata Kunci : residu minyak atsiri, Syzygium aromaticum L., Aedes aegypti, larvasida 


\section{ABSTRACT}

\section{Background}

Vectors controlling using natural insecticide concerned deserves special consideration for the prevention of dengue hemmorhagic fever.Atsiri oil of clove flower has larvicide effect against Aedes aegypti. Good larvicide must has long percistency.

\section{Objective}

Aim of this researched was discovered the larvicidal effect of atsiri oil residue of clove flower as larvicide against III instar larva Ae. Aegypti.

\section{Methods}

This research was a laboratory experiment with randomized post test only control group design. The larvae divided to four concentration group : $0.03 \% \mathrm{v} / \mathrm{v}, 0.3 \% \mathrm{v} / \mathrm{v}, 3 \% \mathrm{v} / \mathrm{v}$, and control. Each group consisted 25 larvae third instar. Observations were made after 48 hours of exposure by counting the number of dead larvae in each group. Larva mortality was observed and measured at week I, II, III, and IV.

\section{Result}

Residual of atsiri oil of clove flower in concentration 0,03\% v/v had larvicide effect among III instar larvae Ae. aegypti mosquito was 91,33\% at week I; was 82,67\% week II; was 37,33\% week III; and was $14 \%$ for concentration 0,03\% v/v. But residual of atsiri oil of clove flower in concentration 0,3\% v/v and 3\% v/v had larvicide effect among III instar larvae Ae. aegypti mosquito $100 \%$ at week I, II, III, and IV.

\section{Conclusion}

Residual of atsiri oil of clove flower had larvacidal effect

\section{Keyword}

Residual of atsiri oil of clove flower, Syzygium aromaticum L, Aedes aegypti, larvacidal

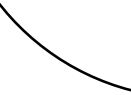

\section{PENDAHULUAN}

Demam Berdarah Dengue (DBD) atau Dengue Hemorrhagic Fever (DHF) adalah penyakit yang disebabkan oleh virus Dengue. Virus ini masuk ke tubuh manusia dengan perantara nyamuk Aedes aegypti dan Aedes albopictus. ${ }^{1}$ Insidensi penyakit ini telah meningkat di seluruh dunia pada satu dekade terakhir. ${ }^{2}$ Penyakit ini cenderung menyebar ke seluruh Indonesia. Puncak penyakit DBD terjadi pada tahun 1988 dengan insidens ratemencapai 13,45\% per 100.000 penduduk. $^{3}$

$$
\text { Penyakit DBD di Provinsi D.I. }
$$

Yogyakarta pada tahun 2007 adalah sebesar 2.578 kasus. ${ }^{4}$ Angka ini meningkat 27,06 \% dibanding pada tahun 2006 yaitu sebesar 
1.887 kasus. $^{4}$ Angka kesakitan tertinggi adalah di wilayah Kota Yogyakarta, disusul Kabupaten Sleman dan Kabupaten Bantul. ${ }^{4}$ Bahkan di Kota Yogyakarta dari tahun ke tahun jumlah penderita yang ditemukan tidak pernah nol. ${ }^{5}$

Sampai sekarang belum ada obat untuk membasmi virus dan vaksin untuk mencegah penyakit DBD. Cara yang tepat guna untuk menanggulangi penyakit ini secara tuntas adalah mengendalikan vektor/nyamuk penular. ${ }^{3}$ Pengendalian vektor DBD stadium pradewasa relatif lebih mudah daripada stadium dewasanya, selain itu kepadatan stadium pradewasa atau larva nyamuk berbanding lurus dengan kejadian luar biasa penyakit DBD. ${ }^{6,7}$

Pengendalian stadium pradewasa dapat dilakukan secara hayati atau kimiawi. ${ }^{6}$ Pengendalian dengan metode kimiawi dianggap lebih efektif karena penurunan populasinya yang cepat. ${ }^{7}$ Pengendalian menggunakan zat kimia banyak menimbulkan masalah seperti meningkatnya resistensi, pencemaran lingkungan, keracunan, kematian hewan bukan sasaran dan residu. ${ }^{8}$ Sehingga perlu dicari larvisida alternatif yang lebih ramah lingkungan. Salah satunya adalah menggunakan senyawa-senyawa kimia alami yang berasal dari tumbuh-tumbuhan. ${ }^{6}$
Salah satu tumbuhan yang memiliki efek larvisida adalah cengkeh (Syzygium aromaticum L.) dengan LC 90 sebesar $0,03 \% \mathrm{v} / \mathrm{v} .{ }^{9}$ Bunganya mengandung minyak atsiri dan juga senyawa kimia lain seperti eugenin, asam oleanolat, asam galotanat, fanilin, kariofilin, resin, dan gom. ${ }^{10}$

Syarat larvisida alternatif adalah harus mempunyai sifat efektif pada dosis rendah, tidak bersifat racun bagi manusia/ mamalia, tidak menyebabkan perubahan rasa, warna dan bau pada air yang diperlakukan, dan efektivitasnya lama. ${ }^{6}$ Larvisida alami memiliki sifat yaitu lebih cepat terurai. ${ }^{11}$ Sifat ini menyebabkan larvisida alami sedikit meninggalkan residu dan tidak menimbulkan resistensi. Sifat ini juga mengakibatkan efektivitas larvisida alami kurang lama.

Informasi terkait efek larvisida residu minyak atsiri bunga cengkeh yang merupakan gambaran dari efektivitas lama dari minyak atsiri bunga cengkeh (Syzygium aromaticum L.) belum pernah ada, sehingga penelitian ini bertujuan untuk mengetahui efek larvisida residu minyak atsiri bunga cengkeh (Syzygium aromaticum L.) terhadap larva instar III nyamuk Ae. aegypti pada minggu ke I, minggu ke II, minggu ke III, dan minggu ke IV. 


\section{METODE PENELITIAN}

Penelitian ini bersifat eksperimental laboratorium dengan rancangan penelitian yang digunakan adalah randomized post test only control group design. Uji yang dilakukan mengacu pada Guidelines for Laboratory and Field Testing of Mosquito Larvicides. ${ }^{12}$ Penelitian dilakukan di Laboratorium Parasitologi Fakultas Kedokteran Universitas Islam Indonesia.selama 4 minggu.

\section{Bahan Uji}

Bahan uji adalah ekstrak minyak atsiri bunga cengkeh yang diperoleh dari daerah Gemawang Temanggung. Bahan kemudian diekstrak di Laboratorium Biologi Fakultas Matematika dan Ilmu Pengetahuan Alam Universitas Islam Indonesia.

Penyulingan minyak atsiri dari bunga cengkeh ini diperoleh dari $1 \mathrm{~kg}$ bunga cengkeh dengan cara destilasi. ${ }^{13}$ Minyak atsiri bunga cengkeh ini dilarutkan dengan Tween 80 sebanyak $1 \mathrm{ml}$ yang diperoleh dari penelitian pendahuluan. Penelitian pendahuluan menunjukkan bahwa Tween 80 sebanyak $1 \mathrm{ml}$ merupakan jumlah minimal yang dapat melarutkan dengan sempurna konsentrasi terbesar yang dipakai pada penelitian ini.

\section{Subjek Uji}

Subyek penelitian ini adalah larva Ae.aegypti instar III.Tiap kelompok uji terdiri dari 25 ekor larva. Larva diperoleh dari kolonisasi di Laboratorium Parasitologi Fakultas Kedokteran Universitas Islam Indonesia Yogyakarta.Larva instar III diperoleh setelah 5 hari penetasan telur. Selama kolonisasi larva diberi makan hati ayam mentah. Suhu ruang pada penelitian ini sebesar $23-26^{\circ} \mathrm{C}, \mathrm{pH} 7$, dan kelembaban $60-76 \%$.

\section{Intervensi}

Larva dimasukkan ke dalam $100 \mathrm{ml}$ akuades yang sudah didiamkan selama 24 jam. Kemudian larva didiamkan 2 jam untuk aklimatisasi. Larva dibagi menjadi empat kelompok $(n=25)$ yaitu kelompok perlakuan dengan konsentrasi $0,03 \% \mathrm{v} / \mathrm{v}$, $0,3 \% \mathrm{v} / \mathrm{v}, 3 \% \mathrm{v} / \mathrm{v}$ dalam Tween 80 sebanyak $1 \mathrm{ml}$ dan kelompok kontrol yang hanya diberi Tween 80 sebanyak $1 \mathrm{ml}$. Tiap konsentrasi dilakukan replikasi sebanyak enam kali.

Nilai mortalitas didapat setelah 48 jam pemaparan bahan uji. Larva yang mati diidentifikasi dengan cara diusik tetapi larva tidak bergerak. 
Selama penelitian volume air tetap dipertahankan $100 \mathrm{ml}$. Setelah satu minggu, volume akuades diambil $25 \mathrm{ml}(25 \%)$ kemudian diganti dengan akuades yang baru sehingga volume tetap $100 \mathrm{ml}$.

Kemudian dimasukkan larva instar III Ae. aegypti ke dalam gelas perlakuan dan kontrol masing-masing 25 ekor dan dihitung mortalitas larva 48 jam kemudian. Hal ini dilakukan selama empat minggu.

\section{Analisis Data}

Pada penelitian ini yang diukur adalah persentase kematian larva setelah diberi perlakuan 48 jam.Pengukuran persentase enam. Hasil penelitian diuji dengan uji Kruskal Wallis yang dilanjutkan dengan uji Mann-Whitney untuk mengetahui kelompok mana yang bermakna dan uji ANNOVA untuk mengetahui perbedaan antar kelompok perlakuan.

\section{HASIL DAN PEMBAHASAN}

Hasil pengamatan pada efek larvisida residu minyak atsiri bunga cengkeh dapat dilihat padaTabel 1 .

Tabel 1 menunjukkan bahwa rata-rata mortalitas larva Ae. aegypti pada minggu ke-1 konsentrasi 0,03\% v/v adalah 91,33\%, konsentrasi $0,3 \% \mathrm{v} / \mathrm{v}$ dan $3 \% \mathrm{v} / \mathrm{v}$ adalah

Tabel 1. Rerata persentase mortalitas larva Ae.aegypti dengan perlakuan minyak atsiri bunga cengkeh

\begin{tabular}{ccccccccc}
\hline $\begin{array}{c}\text { Konsentrasi } \\
\text { perlakuan }(\% \\
\text { v/v) }\end{array}$ & & I & \multicolumn{7}{c}{ II } & III & IV \\
\cline { 2 - 8 } & 91,33 & $p=0,000$ & 82,67 & $p=0,00$ & 37,33 & $p=0,00$ & 14 & $p=0,00$ \\
0,03 & 100 & & 100 & 0 & 100 & 0 & 100 & 0 \\
3 & 100 & & 100 & & 100 & & 100 & \\
Kontrol & 2,67 & & 2,67 & & 2,67 & & 1,33 & \\
\hline
\end{tabular}

kematian larva dilakukan dengan 100\%, dan kontrol adalah 2,67\%. Analisis menghitung jumlah lava uji yang mati dengan uji Kruskal Wallis menunjukkan selama perlakuan kemudian dibandingkan ada perbedaan yang bermakna antara dengan jumlah larva awal sebelum keempat kelompok $(p=0,000)$. Analisis perlakuan. post hoc dengan Mann-Whitney

Rerata persentase kematian masing- menunjukkan ada perbedaan bermakna masing perlakuan pada setiap siklus (satu minggu) diperoleh dari jumlah persentase antara kelompok kontrol dengan kelompok konsentrasi $0,03 \% \mathrm{v} / \mathrm{v} \quad(p=0,03)$, kontrol kematian masing-masing replikasi dibagi 
dengan konsentrasi $0,3 \% \mathrm{v} / \mathrm{v}(p=0,02)$, dan kontrol dengan $3 \% \mathrm{v} / \mathrm{v}(p=0,02)$.

Rata-rata mortalitas minggu ke-2 menunjukkan hasil yaitu kelompok konsentrasi $0,03 \% \quad \mathrm{v} / \mathrm{v}$ adalah $82,67 \%$, residu $0,3 \% \mathrm{v} / \mathrm{v}$ dan $3 \% \mathrm{v} / \mathrm{v}$ adalah $100 \%$, dan kelompok kontrol 2,67\%. Analisis Kruskal Wallis menunjukkan ada perbedaan signifikan di antara keempat kelompok $(p=0,000)$. Analisis post hoc dengan Mann-Whitney menunjukkan ada perbedaan bermakna antara kelompok kontrol dengan kelompok konsentrasi $0,03 \% \mathrm{v} / \mathrm{v} \quad(p=0,003)$, kelompok kontrol dengan konsentrasi residu $0,3 \% \quad \mathrm{v} / \mathrm{v}$ $(p=0,002)$, dan kelompok kontrol dengan residu 3\% v/v $\quad(p=0,002)$. Perbedaan bermakna juga ditunjukkan pada residu $0,03 \% \quad \mathrm{v} / \mathrm{v}$ dengan residu $0,3 \% \quad \mathrm{v} / \mathrm{v}$ $(p=0,022)$ dan residu $0,03 \% \mathrm{v} / \mathrm{v}$ dengan residu 3\% ( $p=0,022)$.

Pada minggu ke-3 didapatkan hasil kelompok residu minyak atsiri bunga cengkeh konsentrasi $0,03 \% \quad \mathrm{v} / \mathrm{v}$ adalah $37,33 \%$, residu $0,3 \% \mathrm{v} / \mathrm{v}$ dan $3 \% \mathrm{v} / \mathrm{v}$ adalah
$100 \%$, dan kontrol adalah $2,67 \%$ v/v. Analisis dengan uji Kruskal Wallis menunjukkan adanya perbedaan yang bermakna antara keempat kelompok ( $p=$ 0,000). Analisis dengan uji Mann-Whitney menunjukkan ada perbedaan bermakna antara kelompok kontrol dengan residu $0,03 \% \mathrm{v} / \mathrm{v}(p=0,003)$, kontrol dengan residu $0,3 \% \mathrm{v} / \mathrm{v}(p=0,002)$, kontrol dengan residu $3 \% \mathrm{v} / \mathrm{v}(p=0,002)$. Perbedaan bermakna juga didapat dari residu $0,03 \% \mathrm{v} / \mathrm{v}$ dengan residu $0,3 \%$ v/v $(p=0,002)$ dan residu $0,3 \%$ $\mathrm{v} / \mathrm{v}$ dengan residu 3\% v/v $(p=0,002)$.

Pengamatan pada minggu ke-4 didapatkan rata-rata mortalitas larva $A e$. aegypti kelompok residu minyak atsiri bunga cengkeh $0,03 \% \mathrm{v} / \mathrm{v}$ adalah $14 \% \mathrm{v} / \mathrm{v}$, residu $0,3 \% \mathrm{v} / \mathrm{v}$ dan residu $3 \% \mathrm{v} / \mathrm{v}$ adalah $100 \%$, sedangkan kontrol 1,33\%. Uji Kruskal Wallis menunjukkan ada perbedaan bermakna diantara keempat kelompok $(p=0,000)$. Dan pada uji MannWhitney menunjukkan hasil yang sama dengan minggu ke-3. 
Tabel 2. Hasil Uji Mann Whitney terhadap Kematian Larva Ae. aegypti Instar III setelah diberi minyak atsiri bunga cengkeh dalam 3 konsentrasi dan residu tiap minggu selama 4 minggu.

\begin{tabular}{|c|c|c|c|}
\hline Minggu ke & Kelompok yang diuji & $\mathbf{P}$ & Hasil Uji \\
\hline \multirow[t]{6}{*}{ I } & Kontrol vs $0,03 \%$ v/v & 0,03 & Bermakna \\
\hline & Kontrol vs $0,3 \%$ v/v & 0,02 & Bermakna \\
\hline & Kontrol vs 3\% v/v & 0,02 & Bermakna \\
\hline & $0,03 \% \mathrm{v} / \mathrm{v}$ vs $0,3 \% \mathrm{v} / \mathrm{v}$ & 0,059 & Tidak bermakna \\
\hline & $0,03 \% \mathrm{v} / \mathrm{v}$ vs $3 \% \mathrm{v} / \mathrm{v}$ & 0,059 & Tidak bermakna \\
\hline & $0,3 \% v / v$ vs $3 \% v / v$ & 1,000 & Tidak bermakna \\
\hline \multirow[t]{6}{*}{ II } & Kontrol vs $0,03 \%$ v/v & 0,003 & Bermakna \\
\hline & Kontrol vs $0,3 \%$ v/v & 0,002 & Bermakna \\
\hline & Kontrol vs $3 \%$ v/v & 0,002 & Bermakna \\
\hline & $0,03 \% \mathrm{v} / \mathrm{v}$ vs $0,3 \% \mathrm{v} / \mathrm{v}$ & 0,022 & Bermakna \\
\hline & $0,03 \% \mathrm{v} / \mathrm{v} \mathrm{vs} 3 \% \mathrm{v} / \mathrm{v}$ & 0,022 & Bermakna \\
\hline & $0,3 \% v / v$ vs $3 \% v / v$ & 1,000 & Tidak bermakna \\
\hline \multirow[t]{6}{*}{ III } & Kontrol vs $0,03 \%$ v/v & 0,003 & Bermakna \\
\hline & Kontrol vs $0,3 \%$ v/v & 0,002 & Bermakna \\
\hline & Kontrol vs $3 \%$ v/v & 0,002 & Bermakna \\
\hline & $0,03 \% \mathrm{v} / \mathrm{v}$ vs $0,3 \% \mathrm{v} / \mathrm{v}$ & 0,002 & Bermakna \\
\hline & $0,03 \% \mathrm{v} / \mathrm{v}$ vs $3 \% \mathrm{v} / \mathrm{v}$ & 0,002 & Bermakna \\
\hline & $0,3 \% v / v$ vs $3 \% v / v$ & 1,000 & Tidak bermakna \\
\hline \multirow[t]{6}{*}{ IV } & Kontrol vs $0,03 \%$ v/v & 0,003 & Bermakna \\
\hline & Kontrol vs $0,3 \%$ v/v & 0,002 & Bermakna \\
\hline & Kontrol vs 3\% v/v & 0,002 & Bermakna \\
\hline & $0,03 \% \mathrm{v} / \mathrm{v}$ vs $0,3 \% \mathrm{v} / \mathrm{v}$ & 0,002 & Bermakna \\
\hline & $0,03 \% \mathrm{v} / \mathrm{v}$ vs $3 \% \mathrm{v} / \mathrm{v}$ & 0,002 & Bermakna \\
\hline & $0,3 \%$ v/v vs $3 \% v / v$ & 1,000 & Tidak bermakna \\
\hline
\end{tabular}

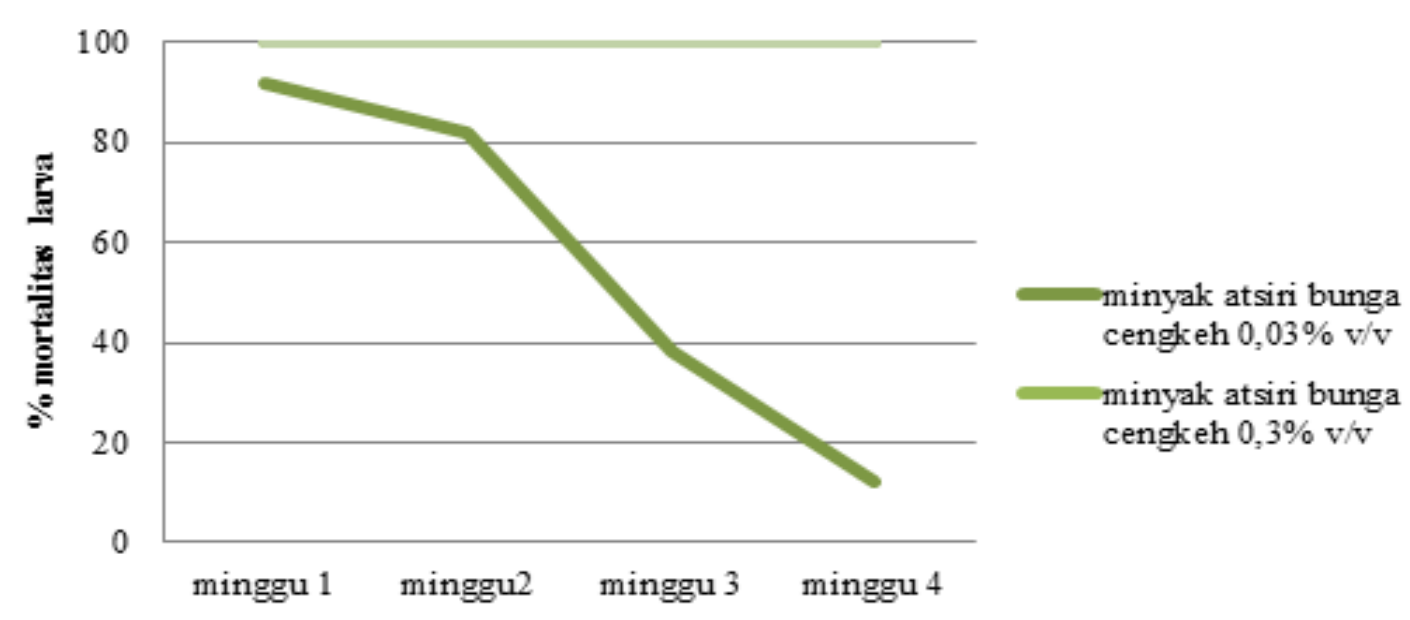

Gambar 1.Mortalitas larva Ae.aegyptidengan berbagai konsentrasi dalam 4 minggu pengamatan 
Pada Gambar 1 terlihat bahwa perbedaan jumlah mortalitas antar waktu pengukuran pada setiap kosentrasi hanya terjadi pada konsentrasi $0,03 \% \quad \mathrm{v} / \mathrm{v}$, sedangkan pada konsentrasi $0,3 \%$ v/v dan $3 \% \mathrm{v} / \mathrm{v}$ tidak terjadi penurunan anggka mortalitas. Uji ANOVA dua arah pada konsentrasi $0,03 \% \quad \mathrm{v} / \mathrm{v}$ terlihat adanya minimal dua waktu pengukuran yang berbeda secara bermakna $(\mathrm{p}=0,04)$. Pada bagian yang kedua (Pairwise Comparasion) terlihat perbedaan yang signifikan antara semua waktu pengukuran $(\mathrm{p}=0,000$ kecuali minggu ke 1 dan 2 yaitu $\mathrm{p}=0,048$ )

Hasil penelitian menunjukkan LC 90 $0,03 \% \mathrm{v} / \mathrm{v}$ menyebabkan mortalitas larva Ae.aegypti yang efektif selama dua minggu. Residu minggu ke-1 menghasilkan rata-rata mortalitas sebesar $91,33 \%$ dan residu minggu ke-2 sebesar 82,67\%. Pada pengamatan minggu ke-3 ataupun 4 kemampuan residu minyak atsiri bunga cengkeh konsentrasi $0,03 \% \mathrm{v} / \mathrm{v}$ menurun secara drastis.

Penurunan tiap minggu pada dosis ini juga cukup signifikan. Hal ini bisa dilihat dari hasil uji ANOVA dua arah dimana mortalitas tiap minggu berbeda secara bermakna. Hal ini dapat dipengaruhi oleh dua karakteristik utama dari insektisida alami, yaitu mudah terurai dan kurang stabil. ${ }^{11}$ Dalam hal ini minyak atsiri bunga cengkeh mudah terurai dan kurang stabil.

Jika dibandingkan dengan residu dari temefos, yang menjadi pilihan dalam pengendalian larva Ae. aegypti, memang efek residunya sangat berbeda jauh. Pada penelitian yang dilakukan oleh Isti'anah. ${ }^{14}$ residu temefos dosis anjuran 1 ppm pada bulan 1 masih memiliki efek mortalitas sebesar 64\%. Bahkan pemerintah menganjurkan temefos diberikan setiap 2-3 bulan sebagai cara pengendalian larva. ${ }^{15}$

Namun, saat konsentrasi ditingkatkan 10 kali dan 100 kali menjadi 0,3\% v/v dan $3 \% \mathrm{v} / \mathrm{v}$ didapatkan tidak terdapat penurunan mortalitas larva Ae.aegypti bahkan setelah diamati hingga minggu ke-5. Hal ini diduga disebabkan kandungan eugenol yang banyak terdapat di minyak atsiri bunga cengkeh. ${ }^{10}$ Eugenol pada air terurai melalui volatisasi dan degaradasi mikroba. ${ }^{11}$ Penguraian yang lambat terjadi pada konsentrasi yang dinaikkan 10 kali dan 100 kali kemungkinan dikarenakan volatisasi pada konsentrasi yang tinggi melambat sejalan dengan tingginya kerapatan partikel yang ada.

Penguraian yang lambat pada konsentrasi yang tinggi memang memberikan keuntungan yaitu frekuensi pemberian minyak atsiri bunga cengkeh 
yang tidak sering.Namun, toksisitas minyak atsiri bunga cengkeh ini juga perlu diperhatikan.Jika konsentrasi dinaikkan, jumlah larva yang menunjukkan gejala toksisitas meningkat. Gejala toksisitas pada larva berupa gerakan yang berkurang dan kemudian larva berada di bawah bejana dengan tremor dan konvulsi kemudian berakhir dengan kematian. ${ }^{17}$

Minyak atsiri bersifat sebagai neurotoksik. Minyak atsiri bunga cengkeh memiliki spektrum yang cukup luas sebagai insektisida. ${ }^{18}$ Namun, toksisitas eugenol, yang merupakan kandungan utama minyak atsiri bunga cengkeh, terhadap mamalia sangat rendah $^{19}$. Toksisitas dapat terjadi jika terpapar dalam konsentrasi tinggi berupa kerusakan hepar. ${ }^{20}$ Konsumsi eugenol maksimal 2,5 mg/kgBB/ hari. $^{21}$ Eugenol dalam konsentrasi 5\% terbukti mempu memberikan kerusakan pada tanaman air seperti Ambrosia artemisiifolia. ${ }^{16}$ Penelitian efek anastesi minyak atsiri pada ikan menunjukkan jika diberikan pada konsentrasi tinggi (100 atau $200 \mathrm{mg} / \mathrm{L}$ ) ikan tersebut mengalami toksisitas dan membutuhkan resusitasi segera. $^{22}$ Dibandingkan dengan data di atas, konsentrasi minyak atsiri bunga cengkeh pada penelitian ini termasuk rendah sehingga kemungkinan terjadi toksisitas dengan konsentrasi tersebut juga berkurang. Namun, perlu dilakukan penelitian lebih lanjut tentang resiko toksisitas terhadap organisme non target.

Resiko toksisitas terhadap organisme non target meningkat sejalan dengan persistensi suatu insektisida. ${ }^{19}$ Berdasarkan sifat ini harus dipertimbangkan lagi penggunaan minyak atsiri bunga cengkeh dalam konsentrasi yang tinggi.Resistensi pestisida sintetik yang sudah terjadi saat ini terjadi karena penggunaan yang tidak tepat.Perlu dicari batas konsentrasi yang aman untuk minyak atsiri bunga cengkeh agar dapat diaplikasikan sebagai larvisida alternatif yang baik dalam masyarakat.

Dalam penelitian ini tidak menggunaan organisme non target sehingga tidak diketahui efek toksisitas minyak atsiti bunga cengkeh terhadap organisme non target.Selain ini dalam penelitian ini hanya digunakan bejana berbahan plastik.Hal ini menyebabkan pengaruh bahan bejana terhadap persistensi minyak astiri bunga cengkeh tidak dapat diketahui.

\section{KESIMPULAN}

1. Terjadi penurunan efek larvisida residu minyak atsiri bunga cengkeh (Syzygium aromaticum L.) konsentrasi 0,03\% v/v pada minggu II, III, dan IV. 
2. Tidak terjadi penurunan efek larvisida residu minyak atsiri bunga cengkeh (Syzygium aromaticum L.) konsentrasi $0,3 \% \mathrm{v} / \mathrm{v}$ dan $3 \% \mathrm{v} / \mathrm{v}$ pada minggu I, II, III, dan IV.

\section{SARAN}

1. Perlu dilakukan penelitian menggunakan berbagai macam bahan bejana untuk mengetahui pengaruh berbagai bahan bejana terhadap persistensi minyak atsiri bunga cengkeh sebagai larvisida.

2. Perlu dilakukan penelitian lebih lanjut tentang pengaruh toksisitas minyak atsiri bunga cengkeh terhadap organisme non target.

3. Perlu dilakukan penelitian lebih lanjut tentang konsentrasi mínimum minyak atsiri bunga cengkeh yang memiliki persistensi cukup baik.

\section{DAFTAR PUSTAKA}

1. Lestari K. Epidemiologi dan Pencegahan Demam Berdarah Dengue (DBD) di Indonesia.Farmaka2007, 5: 3, 12-29.

2. WHO,Dengue: guidelines for diagnosis, treatment, prevention and control, Geneva: WHO Press, 2009.

3. Departemen Kesehatan Republik Indonesia. Kebijaksanaan Program P2 DBD dan Situasi Terkini DBD di Indonesia, 2004, <http://www.depkes.go.id/.>diakses pada tanggal 27 Januari 2011.

4. Dinas Kesehatan Propinsi D. I. Yogyakarta, Profil Kesehatan Propinsi D.I Yogyakarta
Tahun 2008, Yogyakarta: Dinas Kesehatan Propinsi D.I. Yogyakarta, 2009.

5. Dinas Kesehatan Kota Yogyakarta, Pengendalian Penyakit Demam BerdarahDengue(DBD), 2010, <http://kesehatan.jogjakota.go.id/bulletin/i ndex.php?option $=$ com_content $\&$ view $=$ cate gory\&layout $=$ blog $\& i d=41 \&$ Itemid $=55 .>\mathrm{di}$ akses pada tanggal 23 Januari 2011.

6. Suwasono H. Berbagai Cara Pemberantasan Larva Aedes aegypti, Cermin Dunia Kedokteran. 1997, 119, 32-34.

7. Soegijanto S. Demam Berdarah Dengue, edisi 2, Surabaya: University Press, 2006.

Airlangga

8. Munif A. Pengaruh Residu Pyripropoxyfen 0,5\% terhadap Pertumbuhan Larva Aedes aegypti pada Berbagai Simulasi Wadah Air, Cermin Dunia Kedokteran, 1997, 119, 42 46.

9. Sari N. Efek Larvasida Minyak Atsiri Bunga Cengkih (Syzygium aromaticum L.) terhadap Larva Instar IV Nyamuk Aedes aegypti (Karya Tulis Ilmiah). Yogyakarta. Fakultas Kedokteran, Universitas Islam Indonesia. 2009.

10. Agusta A. Minyak Atsiri Tumbuhan Tropika Indonesia. Bandung: Penerbit ITB, 2000.

11. Kardinan A. Pestisida Nabati: Ramuan dan Aplikasi. Jakarta: Penebar Swadaya, 2002.

12. WHO. Guidelines for Laboratory and Field Testing of Mosquito Larvacides, 2005, <http://whqlibdoc.who.int/hq/2005/WHO_ CDS_WHOPES_GC_DPP_2005.13.pdf.>d iakses pada tanggal 15 Februari 2011.

13. Rusli MS. Sukses Memproduksi Minyak Atsiri. Jakarta: Agro Media Pustaka, 2010.

14. Isti'anah, S. Efek Residu Temefos $\left(\right.$ Abate $^{\mathrm{R}}$ ) dan Piroksifen $\left(\right.$ Sumilarv $^{\mathrm{R}}$ ) Terhadap Larva Aedes aegypti dalam Pot Tanaman Air (Tesis). Yogyakarta: Fakultas Kedokteran, Universitas Gadjah Mada. 2009.

15. Sungkar S. Pemberantasan Demam Berdarah Dengue: Sebuah Tantangan yang Harus Dijawab.Majalah Kedokteran Indonesia, 2007, 57(6):167-70.

16. Marin Municipal Water District, Clove Oil (Eugenol), 2008, <http:/marine../.> diakses pada tanggal 28 Oktober 2011. 
17. SutthanontN, Choochote W, Tuetun B, Junkum A, JitpakdA, Chaithong U, Riyong D, Pitasawat, B.Chemical composition and larvicidal activity of edible plant-derived essential oils against the pyrethroidsusceptible and resistant strains of Aedes aegypti (Diptera: Culicidae). Journal of Vector Ecology. 2010, 35 (1): 106-115.

18. Yang YC, Lee SH, Lee WJ, Choi, DH, Ahn YJ. Ovicidal and Adulticidal Effects of Eugenia caryophyllata Bud and Leaf Oil Compounds on Pediculus capitis. Journal Agricultur Food Chemistry. 2003. 51: 4884- 4888.

19. Koul O, Walia S, Dhaliwal GS. Essential Oils as Green Pesticides: Potential and Constraints. Biopesticides International. 2008, 4(1): 63-84

20. FAO, Toxicological Evaluation Of Some Flavouring Substances And Non-Nutritive Sweetening 1999, <http://www.inchem.org/.htm.>, Diakses pada tanggal 28 Oktober 2011.

21. WHO,Eugenol, 1982, <http://www.inchem.org/.htm>, diakses pada tanggal 28 Oktober 2011.

22. Sladky K, Swanson CR, Stoskopf MK, Loomis MR, Lewbart GA. Comparative Efficacy Of Tricaine Methanesulfonate And Clove Oil For Use As Anesthetics In Red Pacu (Piaractus brachypomus).American Journal of Veterinary Research. 2001, 62:337-342. 